\title{
Erratum
}

\section{Gibbosporina, a new genus for foliose and tripartite, Palaeotropic Pannariaceae species previously assigned to Psoroma-ERRATUM}

\section{Arve ELVEBAKK, Soon Gyu HONG, Chae Haeng PARK, Eli Helene ROBERTSEN and Per Magnus JØRGENSEN}

doi:10.1017/S0024282915000328. Published online for the British Lichen Society by Cambridge University Press, 14 January 2016.

The authors have drawn our attention to two errors in this paper (Elvebakk et al. 2016). The generic type species of Gibbosporina on p. 17 and the new combination based on Psoroma boninense Kurok. on p. 29 should both read: Gibbosporina boninensis (Kurokawa) Elvebakk \& P.M. Jørg.

\section{REFERENCE}

Elvebakk, A., Hong, S.G., Park, C.H., Robertsen, E.H. \& Jørgensen, P.M. (2016) Gibbosporina, a new genus for foliose and tripartite, Palaeotropic Pannariaceae species previously assigned to Psoroma. Lichenologist 48 (1): 13-52. 